\title{
Application of immunofluorescence to a study of measles
}

\author{
JOYCE MCQUILLIN, T. M. BELL, P. S. GARDNER, and M. A. P. S. DOWNHAM \\ From the Departments of Virology and Child Health, Royal Victoria Infirmary, Newcastle-upon-Tyne
}

\begin{abstract}
McQuillin, J., Bell, T. M., Gardner, P. S., and Downham, M. A. P. S. (1976). Archives of Disease in Childhood, 51, 411. Application of immunofluorescence to a study of measles. A new and rapid method for the laboratory diagnosis of measles, using the fluorescent antibody technique applied to nasopharyngeal secretions is described. The reliability of the method was best shown by correlation with clinical diagnosis, which gave an overall agreement of $95 \%$ in 53 cases of typical clinical measles and 72 control children. Correlation with results of tissue culture and serology was also good, though these methods are in practice too infrequently successful to be used as the main standards of reliability. The antiserum used for immunoflorescence showed no cross-reactivity with other viruses. Viruses could be identified by the fluorescent antibody technique from 4 days before to 10 days after the onset of the rash in a high proportion of cases.

The wider applications of this method include rapid diagnosis of measles before the rash has appeared; in cases where clinical diagnosis is in doubt, especially in darkskinned children, or when the illness has been modified by previous vaccination; prevention of cross-infection by early detection of measles; and investigation of the immune reponse and its relationship to nutritional status.
\end{abstract}

Although measles can usually be diagnosed from the clinical picture alone, under certain circumstances the aid of laboratory investigation is necessary. Clinical differentiation from other rashes may sometimes be difficult, and this has been especially so since the widespread introduction of measles vaccine, which may modify the clinical features of subsequent infection. Measles can also occur without a rash (Enders et al., 1959; Gardner, Elderkin, and Wall, 1964). The coryzal pre-eruptive phase of measles resembles acute respiratory illnesses caused by other viruses, and differentiation at this stage is often important in the prevention of cross-infection. Clinical diagnosis is sometimes difficult to make with certainty in coloured children. In all these instances a laboratory diagnosis is required which is both accurate and rapid.

Present methods of definitive laboratory diagnosis are isolation of the virus and the demonstration of specific serological responses, neither of which can be considered rapid. Isolation of mealses virus

Received 1 September 1975 is difficult (MacLeod, 1968), owing to the limited sensitivity of tissue culture cells (Enders, 1962) and also to the short period of the illness during which virus can be isolated (Ruckle and Rogers, 1957; Gresser and Katz, 1960). Though examination of paired sera has been the most reliable method of laboratory diagnosis, the difficulties of obtaining these, particularly from children, are well known.

In the past workers have claimed that exfoliated giant cells in nasopharyngeal secretions (NPS) are specific for measles infection (Tompkins and Macaulay, 1955; Beale and Campbell, 1959; Mottet and Szanton, 1961). This finding however has not been adequately confirmed by laboratory virus identification, nor is there sufficient evidence that similar giant cells are not found in other virus infections.

Immunofluorescence has previously been used to show the presence of measles antigen in cells from infected tissue culture (Cohen et al., 1955). LlanesRodas and Liu (1966) detected measles antigen by fluorescence in epithelial cells in urine sediments from cases of active measles from at least 2 days before the rash appeared to a maximum of 6 days 
after. This however has not become an established method, in view of the technical difficulties in transporting and examining urine for virus identification, and the need for a standardized technique for the investigation of all respiratory illnesses.

The ability of the fluorescent antibody (FA) technique, applied to NPS, to provide a rapid and reliable laboratory diagnosis for a range of respiratory virus infections has been established over the past 6 years in the laboratory (Gardner and McQuillin, 1974). The investigations reported in this paper were designed to extend the FA technique, using NPS, to measles virus infections, and in particular to provide a rapid and reliable method of diagnosis for those patients in whom the clinical diagnosis was in doubt.

\section{Materials and methods}

Patients. 131 children admitted to the paediatric wards of the hospitals in Newcastle and Gateshead between May 1972 and January 1974, were investigated for infection with measles virus. A final clinical diagnosis of measles was made in 53 patients, without knowledge of laboratory findings. 10 of these children were admitted before the appearance of the rash with a variety of diagnoses as set out in Table I, and a further 5 patients

\section{TABLE I}

Primary clinical diagnosis in patients admitted during pre-eruptive phase of measles

\begin{tabular}{l|c|c}
\hline \multicolumn{1}{c|}{$\begin{array}{c}\text { Primary clinical } \\
\text { diagnosis }\end{array}$} & $\begin{array}{c}\text { Days before } \\
\text { onset of } \\
\text { rash }\end{array}$ & Age (m) \\
\hline URTI & 6 & 13 \\
Head injury & 5 & 39 \\
Febrile convulsions and & 5 & 34 \\
$\quad$ URTI & 4 & 6 \\
Bronchiolitis (RS virus & 4 & 28 \\
$\quad$ identified) & 4 & 24 \\
Pneumonia & 2 & 22 \\
Peningitis and pneumonia & 2 & 11 \\
Pneumonia & 1 & 15 \\
Bronchible early measles & 1 & \\
URTI & & \\
\hline
\end{tabular}

URTI, upper respiratory tract infection.

RS virus, respiratory syncytial virus.

acquired their infections in hospital. In 6 children. admitted to hospital with a rash, a clinical diagnosis of measles was in doubt. In the remaining 72 admissions the clinical features were not suggestive of measles, though 14 of them had an unexplained rash. These 72 children acted as 'controls' for the investigation. The mean age both of these 72 control children, and of the 53 definite measles cases, was 32 months.

NPS and nose and cough swabs were collected from each patient, usually within 24 hours of admission.
Repeat specimens were collected from 9 patients between 2 and 11 days after the first. Venous blood was also taken from 69 of the children on admission, and 49 of these had second specimens taken.

Measles virus antisera. Antiserum to measles was made by inoculation of rabbits with the Edmonston strain of virus grown to high titre in LLC-MK2 cells. Methods for the preparation, absorption, and specificity testing of antisera for immunofluorescent diagnosis have been fully described elsewhere (Gardner and McQuillin, 1974) and the same methods were applied for measles.

Fluorescent antibody technique. The techniques for the preparation of nasopharyngeal and tissue culture cells for examination by immunoflurescence were as described by Gardner and McQuillin (1974). The indirect FA technique, with appropriate control procedures, was used throughout. A diagnosis by immunofluorescence can be made within 3 hours of receipt of an NPS specimen.

Isolation and identification of measles virus. Preparations of cough swabs and NPS (Gardner and McQuillin, 1968) were inoculated into tubes of Bristol HeLa, HEp2, WI38, and Rhesus monkey kidney (RMK) tissue cultures. Two RMK tubes were inoculated with each specimen; one tube was maintained in medium 199 without serum and incubated in a roller-drum at $33^{\circ} \mathrm{C}$ to isolate other respiratory viruses present, and the second was maintained in medium 199 with $5 \%$ fetal calf serum and incubated in a stationary rack at $37^{\circ} \mathrm{C}$ for isolation of measles virus.

When a syncytial cytopathic effect suggestive of measles virus was observed, the cultures were tested for their ability to haemadsorb African green monkey erythrocytes. If the result was positive the cells were scraped off the glass, a small aliquot passed to fresh RMK cells, and the remainder fixed onto a slide and examined for the presence of measles antigen by FA technique. A diagnosis of measles by isolation of virus was never made in less than 9 days. The small number of isolates which passaged successfully in RMK cells were passaged twice in Vero cells and then were neutralized using hyperimmune rabbit antiserum. Other viruses recovered on all cell lines during the survey were identified as previously described (Sturdy, McQuillin, and Gardner, 1969). Uninoculated tubes from each batch of RMK cells were observed in parallel with each group of specimens to eliminate the possibility of infection with MINIA virus.

Complement fixation tests. Complement fixation (CF) tests were performed by the microtitre system (Bradstreet and Taylor, 1962) using a standard measles antigen supplied by the Central Public Health Laboratory, Colindale.

Haemagglutination inhibition tests. The Edmonston strain of measles virus was grown in LLC-MK2 
cells. The haemagglutinin was titrated at $37^{\circ} \mathrm{C}$ in WHO trays, one unit calculated, and four units used in the test (Enders-Ruckle, 1965). Due to the relatively large volumes required, not all specimens could be tested by the haemagglutination inhibition (HI) test.

\section{Results}

Appearance of fluorescence. The appearance of measles virus in RMK cells, stained by the indirect FA technique, is shown in Fig. 1. The fluoresence is both intracytoplasmic and intranuclear, sometimes diffuse and sometimes particulate. The measles virus-infected cells in nasopharyngeal secretions present a wide variety of appearances. In some secretions only small round, or occasionally ciliated cells may show fluorescence (Figs. 2 and 3), but in others there may be large numbers of giant cells (Fig. 4). As with infected tissue culture cells,

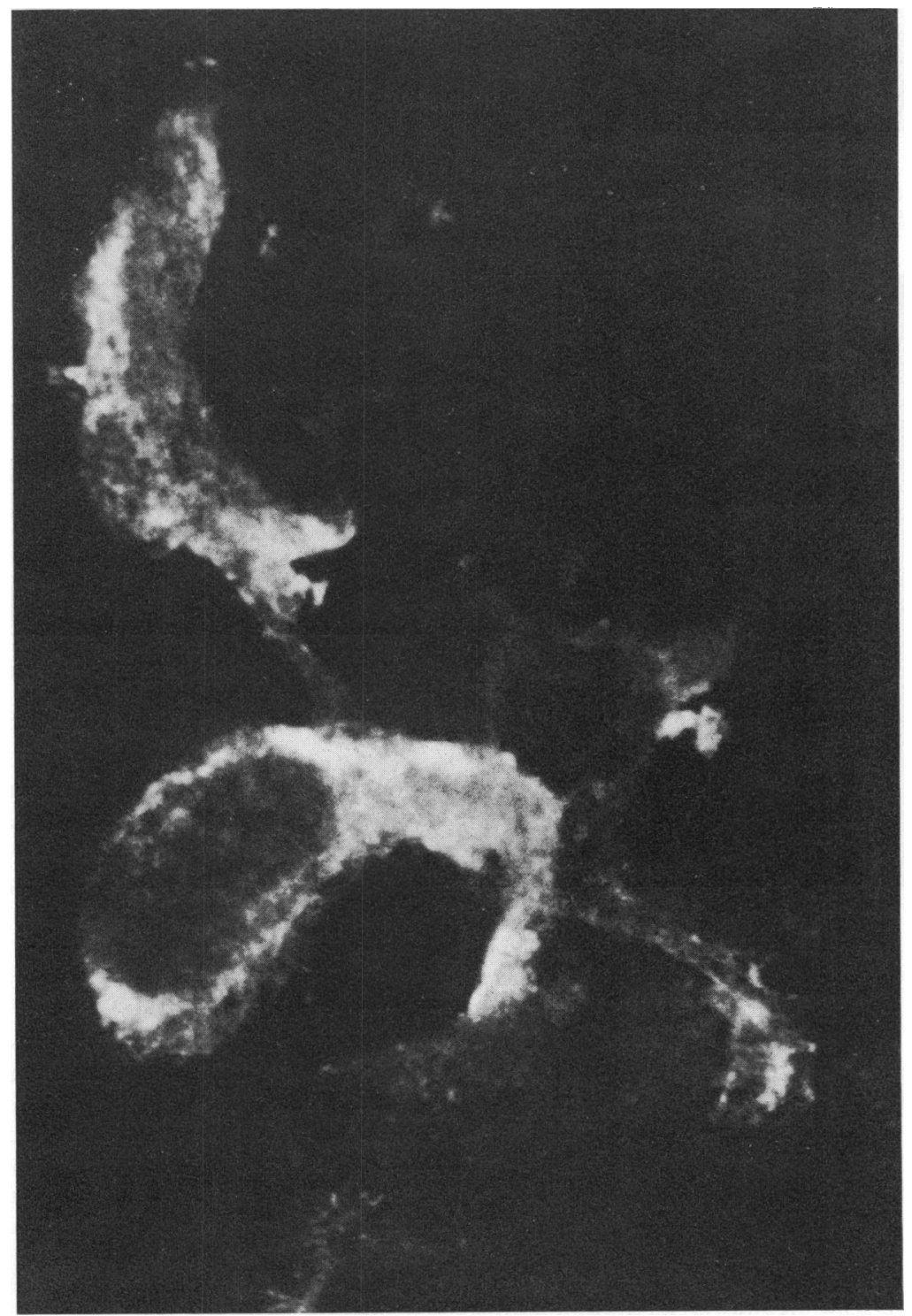

FIG. 1.-Measles virus-infected Rhesus monkey kidney cells stained by the indirect fluorescent antibody technique. $(\times 1400$. 


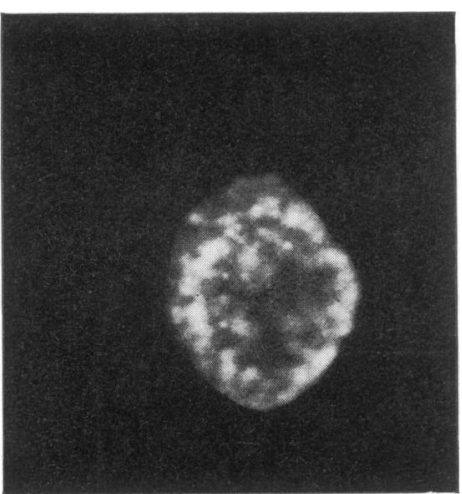

FIG. 2.-Measles virus antigen in a small round cell in a nasopharyngeal secretion, stained by the indirect fluorescent antibody technique. $(\times 1400$.

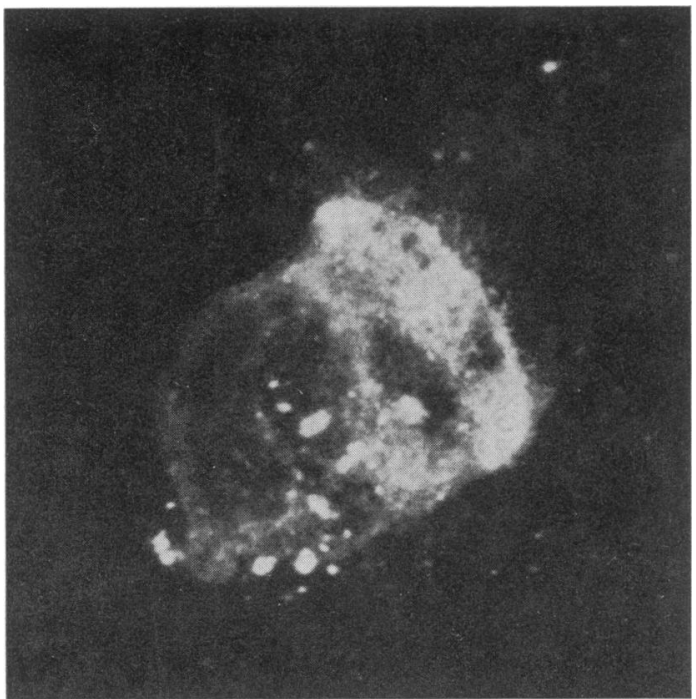

FIG. 3.-A cluster of measles virus-infected ciliated respiratory epithelial cells in a nasopharyngeal secretion, stained by the indirect fluorescent antibody technique. $(\times 1100$.

the fluorescence may be intracytoplasmic or intranuclear, sometimes with well-defined particles (Fig. 3) and sometimes diffuse (Fig. 4).

Relation of FA technique to clinical diagnosis. The laboratory results and clinical diagnosis are correlated in Table II. Measles antigen was shown by FA technique in 47 of 53 children with definite clinical measles, in 2 of the 6 children with a possible diagnosis of measles, and in none of the 72 patients without clinical measles. Of the 6

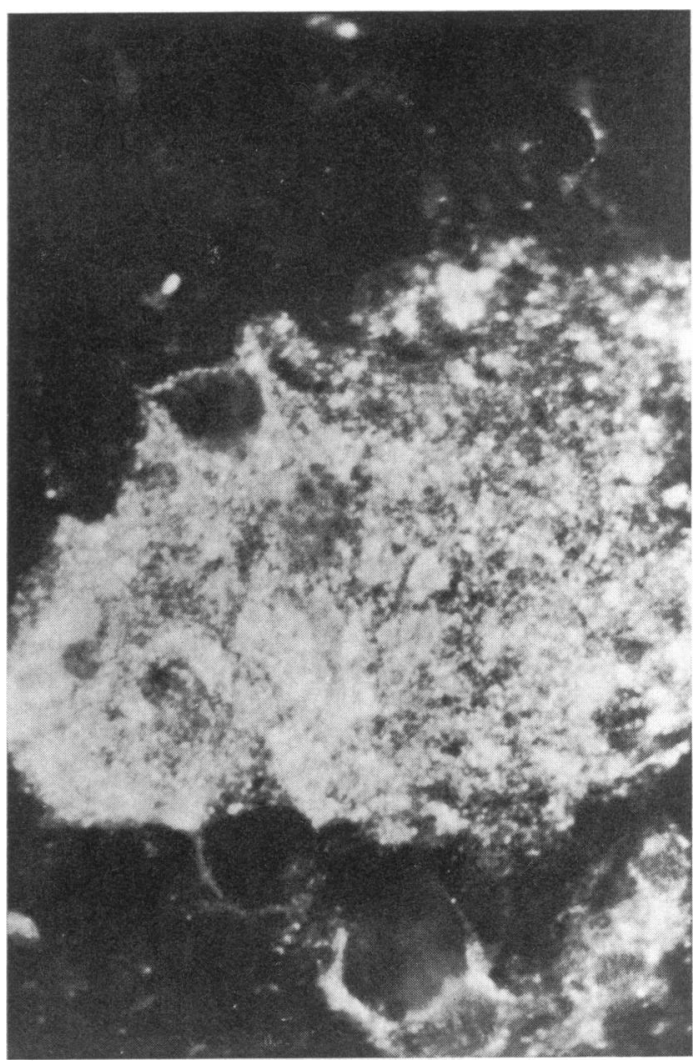

FIG. 4.-Measles virus antigen in a giant cell in a nasopharyngeal secretion, stained by the indirect fluorescent antibody technique. $(\times 960$.

patients with definite clinical measles whose NPS were negative by FA technique, secretions were collected 5 or 6 days after the onset of the rash from 4, 2 days after onset from 1 , and 1 day after onset from the sixth. This last child had been vaccinated 10 months previously.

\section{Specificity of the FA technique.}

Cross-reactivity with other viruses. Although a variety of viruses other than measles occurred in approximately one-quarter of the NPS of this series, the measles antiserum did not show any cross-reactions with them. Viruses were isolated from the NPS of 25 of the 72 'control' patients (8 adenovirus; 4 RS virus; 2 each of herpesvirus hominis and echovirus type $9 ; 1$ each of mumps, parainfluenza 1 , parainfluenza 3 , parainfluenza $4 b$, vaccinia, Coxsackie $\mathrm{A} 9$, and Coxsackie $\mathrm{B} 1 ; 1$ $\mathrm{H}$-strain rhinovirus and parainfluenza 3 dual infection; and 1 RS virus and adenovirus dual 
TABLE II

Correlation of clinical diagnosis with laboratory results

\begin{tabular}{|c|c|c|c|c|c|c|}
\hline \multirow[b]{2}{*}{ Test } & \multicolumn{2}{|c|}{ Definite clinical measles } & \multicolumn{2}{|c|}{ Possible clinical measles } & \multicolumn{2}{|c|}{ Not clinical measles } \\
\hline & $\begin{array}{l}\text { No. } \\
\text { tested }\end{array}$ & $\begin{array}{c}\text { No. } \\
\text { positive }\end{array}$ & $\begin{array}{l}\text { No. } \\
\text { tested }\end{array}$ & $\begin{array}{c}\text { No. } \\
\text { positive }\end{array}$ & $\begin{array}{l}\text { No. } \\
\text { tested }\end{array}$ & $\begin{array}{c}\text { No. } \\
\text { positive }\end{array}$ \\
\hline $\begin{array}{l}\text { Fluorescent } \\
\text { antibody (FA) } \\
\text { Isolation } \\
\text { FA + ve } \\
\text { FA-ve } \\
\text { Rise in CFT } \\
\text { antibody } \\
\text { FA + ve } \\
\text { FA-ve } \\
\text { Rise in HI } \\
\text { antibody } \\
\text { FA + ve } \\
\text { FA-ve }\end{array}$ & $\begin{array}{r}53 \\
47 \\
6 \\
\\
\\
16 \\
2 \\
\\
13 \\
2\end{array}$ & $\begin{array}{r}47 \\
13 \\
0\end{array}$ & $\begin{array}{l}6 \\
2 \\
4\end{array}$ & $\begin{array}{l}2 \\
1 \\
0\end{array}$ & $\begin{array}{r}72 \\
0 \\
72 \\
\\
0 \\
31 \\
\\
0 \\
23\end{array}$ & $\begin{array}{l}0 \\
0 \\
0\end{array}$ \\
\hline
\end{tabular}

Note: An antibody rise was considered positive if the titre rose by fourfold or greater.

Correlation of definite clinical diagnosis with fluorescent antibody test result, by the method of Buck and Gart (1966). Copositivity 47/53, $88 \cdot 7 \%$; conegativity $72 / 72,100 \%$; overall agreement $119 / 125,95 \cdot 2 \%$.

infection). All 25 NPS were negative for measles when tested by FA technique, as were the remaining 47 'controls'.

Correlation with virus isolation. Measles virus was isolated from 14 patients, in all of whom specimens were positive by the FA technique. Virus was never grown from a patient who did not have measles antigen shown by immunofluorescence.

Correlation with serology. Paired sera were obtained from only 49 patients, 18 of whom had clinical measles. Corrrelation of the results of these specimens with the examination of cells in secretions by FA technique is shown in Table III.

\section{TABLE III}

Correlation of fluorescent antibody test with seroconversion.

\begin{tabular}{l|c|c}
\hline $\begin{array}{c}\text { Result of } \\
\text { fluorescent } \\
\text { antibody test }\end{array}$ & $\begin{array}{c}\text { Measles infection } \\
\text { diagnosed by } \\
\text { seroconversion }\end{array}$ & $\begin{array}{c}\text { Failure to diagnose } \\
\text { measles by } \\
\text { seroconversion }\end{array}$ \\
\hline Positive & 15 & 1 \\
Negative & 1 & 32 \\
\hline
\end{tabular}

The one negative NPS from a child with a positive serological diagnosis, was collected late in the illness -6 days after onset of rash. The child whose NPS was positive without serological confirmation showed high but only twofold rising antibody titres to measles antigen, presumably because there was only a 6-day interval between the two blood specimens.

Demonstration of virus in relation to onset of rash. The results of the FA technique and isolation attempts on all specimens from the 53 patients with definite clinical measles are listed in Table IV, in relation to the time of appearance of the rash. Specimens were collected between 2 days before and 2 days after onset of rash from 12 of the 14 patients from whom measles virus was successfully grown. Only two further isolations were made from the specimens collected up to 5 days after the appearance of the rash and none thereafter. The FA technique, on the other hand, enabled the demonstration of measles antigen in all but 2 of the 51 NPS collected from 4 days before to 4 days after the rash appeared. From the onset of rash to the tenth day after, $84 \%$ of the 61 specimens were positive for measles antigen by FA technique, in contrast to an isolation rate of only $15 \%$.

Serial specimens of NPS, taken at varying time intervals from 9 patients, were examined by immunofluorescence and isolation techniques for the presence of measles virus. The results were recorded in Table V. Virus was detected over a period of 8 days in 3 children (Cases 3, 26, 55). Secretions from 5 children in whom measles virus antigen was detected by FA technique in secretions collected early in the illness became negative between 6 and 8 days after the appearance of the rash (Cases 1, 16, 38, 46, 55). 
TABLE IV

Demonstration of measles virus in relation to onset of rash

\begin{tabular}{|c|c|c|c|c|}
\hline \multirow{2}{*}{$\begin{array}{c}\text { Days from } \\
\text { onset of } \\
\text { rash }\end{array}$} & \multicolumn{2}{|c|}{ Fluorescent antibody } & \multicolumn{2}{|c|}{ Isolation } \\
\hline & Positive & Negative & Positive & Negative \\
\hline $\begin{array}{c}-8 \\
-5 \\
-4 \\
-3 \\
-2 \\
-1 \\
\text { Day of onset } \\
+1 \\
+2 \\
+3 \\
+4 \\
+5 \\
+6 \\
+7 \\
+8 \\
+10\end{array}$ & $\begin{array}{r}0 \\
0 \\
1 \\
2 \\
1 \\
4 \\
9 \\
10 \\
9 \\
6 \\
7 \\
3 \\
5 \\
1 \\
0 \\
1\end{array}$ & $\begin{array}{l}1 \\
1 \\
0 \\
0 \\
0 \\
0 \\
0 \\
1 \\
1 \\
0 \\
0 \\
1 \\
3 \\
2 \\
2 \\
0\end{array}$ & $\begin{array}{l}0 \\
0 \\
0 \\
0 \\
1 \\
4 \\
2 \\
4 \\
1 \\
0 \\
1 \\
1 \\
0 \\
0 \\
0 \\
0\end{array}$ & $\begin{array}{l}1 \\
1 \\
1 \\
2 \\
0 \\
0 \\
7 \\
7 \\
9 \\
6 \\
6 \\
3 \\
8 \\
3 \\
2 \\
1\end{array}$ \\
\hline
\end{tabular}

TABLE V

Duration of measles virus antigen in secretions

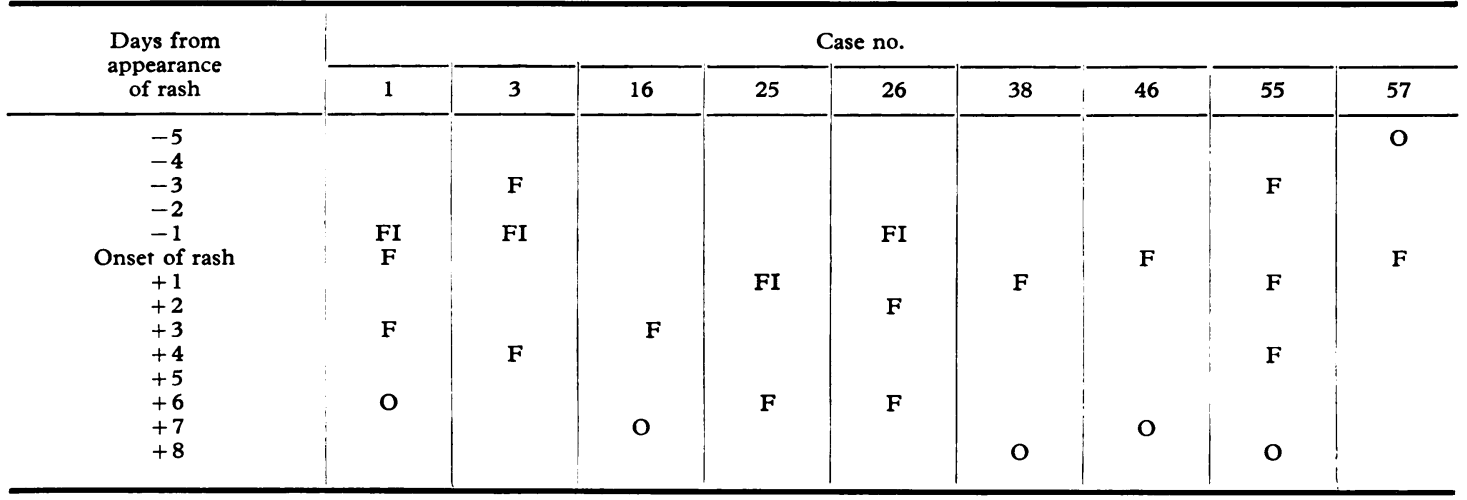

F, NPS positive by fluorescent antibody; I, NPS positive by isolation; O, NPS negative by fluorescent antibody.

Presence of giant cells in relation to onset of rash. A total of 57 specimens of NPS in which measles antigen was detected by FA technique was examined for the presence of giant cells containing fluorescent antigen (Fig. 4). Varying numbers of giant cells were found in specimens collected between 3 days before and 7 days after the appearance of the rash (Fig. 5). A large proportion (27/32) of the specimens collected from 2 days before to 2 days after onset of the rash contained giant cells, whereas only 10 out of 25 of those collected at other times contained such cells.

Relative sensitivity of $\mathrm{CF}$ and $\mathrm{HI}$ tests for serological diagnosis. Seroconversion was shown more frequently by the CF (16 out of 18) than by the HI test ( 9 out of 15). Though paired serum specimens were available from only 18 of the definite measles cases, single specimens were obtained from another 23 patients making a total of 59 specimens tested by CF and 52 by HI. The individual titres of these specimens have been plotted in relation to the time of appearance of the rash (Fig. 6). For both CF and HI antibodies there is a statistically significant relationship between the titre and the time of appearance of the rash from 5 days before to 10 days after. Beyond 10 days this relation no longer exists, and a mean titre can be calculated. The slopes of the two lines do not differ significantly, but $\mathrm{HI}$ antibodies appear significantly earlier than CF antibodies. As both antibodies increase at approximately the same rate, 


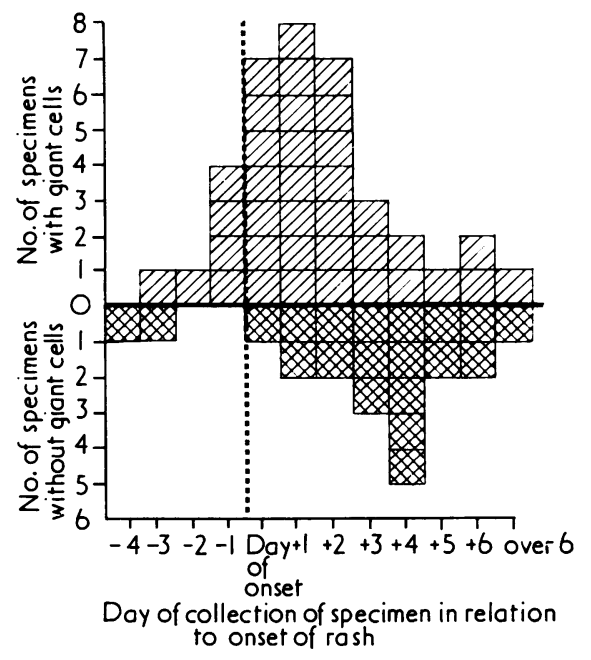

FIG. 5.-Presence of giant cells containing measles antigen in nasopharyngeal secretion with fluorescent antibodydetected measles antigen.

and reach their maximum titre at the same time, HI titres are approximately eightfold greater than those obtained by CF test.

Relation of FA technique results, antibody titre, and virus isolation to onset of rash. If the results of the examination of all specimens from the 53 children with clinical measles are combined into one graph (Fig. 7), an overall pattern emerges. The curves expressing the ability of the FA and isolation techniques to detect measles virus have similar shapes, but the curve for isolation has a much

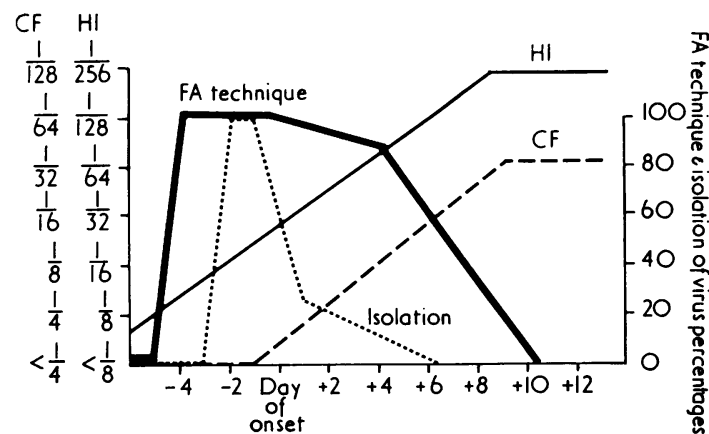

Fig. 7.-Relationship of antigen detection by fluorescent antibody, virus insolation, and antibody titres to onset of measles rash.

narrower peak. This shows that the FA technique can be relied upon over a much greater time interval than virus isolation techniques for the laboratory diagnosis of measles. The very eariy appearance of $\mathrm{HI}$ antibodies is shown, and also that peak antibody titres and disappearance of virus antigen from cells in NPS occur at approximately the same time.

\section{Discussion}

Over the past 6 years the FA technique has been successfully used in this laboratory as a method for the rapid diagnosis of infection with $R S$ virus, parainfluenza virus types 1,2 , and 3 , influenza $A$ and $B$, and adenovirus (Gardner and McQuillin, 1974). In infections with these respiratory viruses the positive fluorescence observed in cells of NPS can be confirmed by isolation of the virus, and the

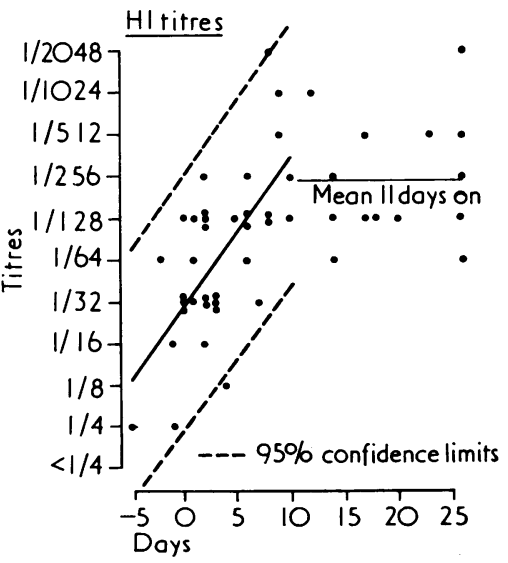

FIG. 6.-Analysis of antibody titres in individual serum specimens from children with measles in relation to the onset of rash. 
specificity of the technique has been proved beyond doubt.

Application of the technique to the rapid diagnosis of measles has presented a new problem because of the difficulties in isolating virus. The results of this survey for isolation of measles virus from the nasopharynx were similar to those in previous studies (Enders, 1962; Ruckle and Rogers, 1957). Virus isolation from respiratory tract specimens, even using the specialized techniques described, was successful in only a small proportion of our children with definite clinical measles (13 out of 53). This low isolation rate was due mainly to the fastidious nature of measles virus in tissue culture. Furthermore, the majority of children with measles do not present until after onset of the rash, but the optimum time for isolation of virus is during the pre-eruptive phase of the illness (Table IV). For these reasons the specificity of the FA technique for measles cannot be assessed solely by virus isolation.

Although serological diagnosis is possible in the majority of patients, since children with measles are usually immunologically mature and show a good serological response to infection with the virus, it is often difficult to obtain a second blood specimen, particularly from mildly ill children who have been discharged from hospital. When paired sera are available, we have shown that the CF is more reliable than the $\mathrm{HI}$ test for laboratory diagnosis (Fig. 6). However, unlike most other respiratory viruses, which can produce a wide range of nonspecific clinical syndromes, measles virus produces a characteristic clinical picture. The clinical features in typical cases can be taken as evidence of measles virus infection, and can therefore be used as one of the criteria for assessment of the specificity of the FA technique.

The reliability of the FA technique was thus strongly supported by the finding that it was positive in a high proportion of children with a typical measles clinical picture (47 out of 53), was less frequently positive when measles diagnosis was in doubt (2 out of 6 ), and was not shown in a single patient where measles was not suspected clinically (Table II). Isolation and serology between them confirmed the presence of measles infection in only 24 out of 53 patients with definite clinical measles. However, the isolations of the virus which were obtained coincided completely with the detection of virus antigen in NPS by FA technique (Table II). There was also a strong correlation between the results of serological tests and the detection of measles by FA technique (Table III). Specificity of the method was further substantiated by the negative results obtained in the examination of 25 secretions which contained a variety of viruses other than measles and in 47 secretions negative on culture from patients with no clinical evidence of measles.

One of the most important applications of this technique is in the diagnosis of the pre-eruptive stage of measles. 10 of the 53 patients who were finally diagnosed as clinical measles were admitted to hospital before the appearance of the rash (Table I). Measles was suspected in only one of these children on admission, so that in the other 9 the clinical value of the laboratory diagnosis is apparent.

A further clinical application of the FAT technique is for the rapid differentiation of measles from other rashes, where the clinical diagnosis is in doubt. Diagnostic uncertainty is most likely to occur during the early stages of the rash, and especially when previous vaccination may have modified the clinical picture. 6 children in this series presented with a rash doubtfully suggestive of measles; in 2 of them the FA technique established a diagnosis of measles, while specimens from the other 4 were negative despite collection at the optimum time for antigen detection. Only 4 children among those with definite or doubtful clinical measles had been vaccinated in the past. In 2 of these the clinical diagnosis was doubtful, and FA was positive in one. The other 2 children had definite clinical measles, but the FA was positive in only 1 of the 2 . The FA technique may therefore be of some value in the diagnosis of cases modified by previous vaccination, but the numbers of vaccinated children in this series were too small to allow a critical evaluation.

Five of the children included in this survey became infected with measles while in hospital for other illnesses. The frequency of cross-infection is similar to that seen with other respiratory viruses (Gardner et al., 1973). The ability of the technique to rapidly and accurately differentiate the preeruptive stage of measles from other respiratory virus infections has already proved helpful in the control of measles cross-infection in paediatric wards. Diagnosis by FA technique on NPS can be made within 3 hours after collection of specimens, so that measles infections can be confirmed on the day the child is admitted to hospital.

The pathogenesis of measles has been related to the immune response of the host (British Medical Journal, 1973), and the duration of excretion of giant cells exfoliated from the respiratory tract is probably also related to these responses (Scheifele and Forbes, 1972). The period of from 5 days before to 8 days after the appearance of the rash, during which shedding of giant cells has been shown 
to occur in uncomplicated measles (Tompkins and Macaulay, 1955; Scheifele and Forbes, 1972), coincides with that during which we have detected measles antigen in NPS by immunofluorescence. Our demonstration of measles antigen in giant cells (Fig. 4) supports the presence of such cells on histological examination as indicating concurrent measles infection. However, the information available about histological findings in other kinds of respiratory tract infection is inadequate, and it may well be that immunofluorescence is a more specific method of detecting continuing virus secretion and assessing immune response than simple histological examination for giant cells. We plan to undertake parallel histological and immunofluorescent studies of specimens from children both with measles and with other respiratory infections to establlsh this point. The FA technique may then prove an important tool in the investigation of the pathogenesis of severe measles, and its relation to nutritional status. Furthermore, severe measles is predominantly a disease of darkskinned children, in whom, whether in this country or abroad, the diagnosis more often requires a reliable method of laboratory confirmation than in white-skinned children.

We are indebted to the Scientific and Research SubCommittee of the Royal Victoria Infirmany for their support, to the ward sisters and medical staff of all the hospitals and the staff of the Department of Virology, Royal Victoria Infirmary, for their collaboration, and to Mrs. Doris Weightman, Department of Medical Statistics, for assistance with the statistics.

\section{REFERENCES}

Beale, A. J., and Campbell, W. (1959). A rapid cytological method for the diagnosis of measles. Fournal of Clinical Pathology. 12, 335.

Bradstreet, C. M. P., and Taylor, C. E. D. (1962). Technique of complement-fixation test applicable to the diagnosis of virus diseases. Monthly Bulletin of the Ministry of Health and the Public Health Laboratory Service, 21, 96.
British Medical fournal, (1973). (Editorial.) Pathogenesis of measles, 3, 187.

Buck, A. A., and Gart, J. J. (1966). Comparison of a screening test and a reference test in epidemiologic studies. American fournal of Epidemiology, 83, 586.

Cohen, S. M., Gordon, I., Rapp, F., Macaulay, J. C. and Buckley, S. M. (1955). Fluorescent antibody and complement-fixation tests of agents isolated in tissue culture from measles patients. Proceedings of the Society for Experimental Biology and Medicine, 90, 118 .

Enders, J. F. (1962). Measles virus. American fournal of Diseases of Children, 103, 282

Enders, J. F., McCarthy, K., Mitus, A., and Cheatham, W. J. (1959). Isolation of measles virus at autopsy in cases of giantcell pneumonia without rash. Nerv England fournal of Medicine, 261, 875.

Enders-Ruckle, G. (1965). Methods of determining immunity, duration and character of immunity resulting from measles. Archiv für die gesamte Virusforschung, 16, 182.

Gardner, P. S., and McQuillin, J. (1968). Appliction of immunofluorescent antibody technique in rapid diagnosis of respiratory syncytial virus infection. British Medical fournal, 3, 340.

Gardner, P. S., and McQuillin, J. (1974). Rapid Virus Diagnosis: Application of Immunofluorescence. Butterworth, London.

Gardner, P. S., Elderkin, F. M., and Wall, A. H. (1964). Serological study of respiratory syncytial virus infection in infancy and childhood. British Medical fournal, 2, 1570.

Gardner, P. S., Court, S. D. M., Brocklebank, J. T., Downham, M. A. P. S., and Weightman, D. (1973). Virus cross-infection in paediatric wards. British Medical fournal, 2, 571.

Gresser, I., and Katz, S. L. (1960). Isolation of measles virus from urine. New England fournal of Medicine, 263, 452.

Llanes-Rodas. R., and Liu, C. (1966). Rapid diagnosis of measles from urinary sediments with fluorescent antibody. New England fournal of Medicine, 275, 516.

MacLeod, D. R. E. (1968). Measles. Textbook of Virology, 5th ed., p. 468. Ed. by A. J. Rhodes and C. E. van Rooyen. Williams and Wilkins, Baltimore.

Mottet, N. K., and Szanton, V. (1961). Exfoliated measles giant cells in nasal secretions. Archives of Pathology, 72, 434.

Ruckle, G., and Rogers, K. D. (1957. Studies with measles virus. II. Isolation of virus and immunologic studies in persons who have had the natural disease. fournal of Immunology, 78, 341.

Scheifele, D. W., and Forbes, C. E. (1972). Prolonged giant cell excretion in severe African measles. Pediatrics, 50, 867.

Sturdy, P. M., McQuillin, J., and Gardner, P. S. (1969). A comparative study of methods for the diagnosis of respiratory virus infections in childhood. Fournal of Hygiene, 67, 659.

Tompkins, V., and Macaulay, J. C. (1955). A characteristic cell in nasal secretions during prodromal measles. Fournal of the American Medical Association, 157, 711.

Correspondence to Prof. P. S. Gardner, Department of Virology, Royal Victoria Infirmary, Newcastle-uponTyne NE1 4LP. 